\title{
Psychological and pedagogical research of the axiosphere of the younger generation as one of the activities of the Technopark
}

\section{A investigação psicológica e pedagógica da axiosfera da geração mais jovem como uma das atividades do Tecnoparque}

\section{Investigación psicológica y pedagógica de la axiosfera de la generación más joven como una de las actividades del Tecnoparque}

\author{
Alexander Mikhailovich Gerashchenko ${ }^{1}$ iD,$T^{2}$ Tatyana Leonidovna Shaposhnikova1 ${ }^{1}$, \\ Oksana Roaldovna Tuchina1 ${ }^{1 D}$, Olga Antonovna Gordienko ${ }^{1}$ iD, Alena Yuryevna Egorova ${ }^{1}$
}

${ }^{1}$ Kuban State Technological University, Krasnodar, Russian Federation.

Corresponding author:

Oksana Roaldovna Tuchina

Email: tuchena@yandex.ru

How to cite: Gerashchenko, A. M., Shaposhnikova, T. L., Tuchina, O. R., Gordienko, O. A., \& Egorova, A. Y.

(2021). Psychological and pedagogical research of the axiosphere of the younger generation as one of the activities of the Technopark. Revista Tempos e Espaços em Educação, 14(33), e15620.

http://dx.doi.org/10.20952/revtee.v14i33.15620

\begin{abstract}
Additional, creatively oriented education of the younger generation of Russians in school technoparks requires studying the characteristics of Generation Z. The values were compared as noted by respondents (1st-year students and university entrants) among different generations of Russians: their own world (the world of children), the world of parents and the world of grandparents. All the three generations are dominated by being oriented towards hard work, study, mutual assistance both within the global environment and within a small society, that is, within family. These positions are represented by the phraseological layers of the language, which indicates their presence in the Russian national value worldview. In the world of parents and in that of children, the emergence of new groups of values absent in the world of grandparents is recorded: orientation towards consumer values, perceived from advertising in the media, and at the same time the extinction of the value of serving the homeland. A new value stands out in the world of children - a humorous approach to life problems, which can be considered global because it contains quotations from world literature and borrowed phraseological units. This value is distinguished by an optimistic view of the world and the role of man in it, which is characteristic of youth. The research results allow asserting that Generation $\mathrm{Z}$ is ready to be creative and is oriented towards technology. Taking into account the peculiarities of the generation allows scientifically organizing educational leisure activities in technoparks.
\end{abstract}


Keywords: Technopark. Axiosphere. Generation Z. Subculture. Picture of the world.

\section{RESUMO}

A educação adicional orientada para a criatividade da geração mais jovem de russos em tecnoparques escolares requer o estudo das características da Geração Z. Os valores foram comparados conforme observado pelos entrevistados (alunos do primeiro ano e ingressantes na universidade) entre diferentes gerações de russos: seu próprio mundo (o mundo das crianças), o mundo dos pais e o mundo dos avós. Todas as três gerações são dominadas por serem orientadas para o trabalho árduo, o estudo, a ajuda mútua tanto no ambiente global quanto dentro de uma pequena sociedade, isto é, dentro da família. Essas posições são representadas pelas camadas fraseológicas da língua, o que indica sua presença na visão de mundo dos valores nacionais russos. No mundo dos pais e no dos filhos, registra-se a emergência de novos grupos de valores ausentes no mundo dos avós: a orientação para os valores de consumo, percebidos na publicidade na mídia, e ao mesmo tempo a extinção do valor dos servindo a pátria. Um novo valor se destaca no mundo infantil - uma abordagem humorística dos problemas da vida, que pode ser considerada global porque contém citações da literatura mundial e unidades fraseológicas emprestadas. Esse valor se distingue por uma visão otimista do mundo e do papel do homem nele, que é característico da juventude. Os resultados da pesquisa permitem afirmar que a Geração $Z$ está pronta para ser criativa e voltada para a tecnologia. Levar em consideração as peculiaridades da geração permite organizar cientificamente atividades educacionais de lazer em tecnoparques.

Palavras-chave: Technopark. Axiosfera. Geração Z. Subcultura. Imagem do mundo.

\section{RESUMEN}

La educación adicional y orientada a la creatividad de la generación más joven de rusos en los tecnoparques escolares requiere el estudio de las características de la Generación Z. Los valores fueron comparados como lo señalaron los encuestados (estudiantes de primer año y estudiantes que ingresan a la universidad) entre diferentes generaciones de rusos: su propio mundo (el mundo de los niños), el mundo de los padres y el mundo de los abuelos. Las tres generaciones están dominadas por estar orientadas hacia el trabajo duro, el estudio, la asistencia mutua tanto dentro del entorno global como dentro de una sociedad pequeña, es decir, dentro de la familia. Estas posiciones están representadas por las capas fraseológicas del idioma, lo que indica su presencia en la cosmovisión del valor nacional ruso. En el mundo de los padres y en el de los hijos se registra la emergencia de nuevos grupos de valores ausentes en el mundo de los abuelos: orientación hacia los valores del consumidor, percibida desde la publicidad en los medios, y al mismo tiempo la extinción del valor de los abuelos. al servicio de la patria. Un nuevo valor se destaca en el mundo de los niños: un enfoque humorístico de los problemas de la vida, que puede considerarse global porque contiene citas de la literatura mundial y unidades fraseológicas prestadas. Este valor se distingue por una visión optimista del mundo y el papel del hombre en él, que es característico de la juventud. Los resultados de la investigación permiten afirmar que la Generación Z está lista para ser creativa y está orientada hacia la tecnología. Tener en cuenta las peculiaridades de la generación permite organizar científicamente actividades de ocio educativo en tecnoparques.

Palabras clave: Tecnoparque. Axiosfera. Generación Z. Subcultura. Imagen del mundo.

\section{INTRODUCTION}

A school technopark, like a technopark of a larger scale (at the level of a city, region, or country), allows attracting creative youth to research work and forming creative teams. A unique feature of the school technopark is educational and developmental leisure activities with schoolchildren mainly according to technically oriented curricula. This allows identifying the orientation of individual students and organizing the learning according to interests in small creative 
groups, for instance, conducting training through project activities when a creative task prompts one to turn to special literature, to set cognitive tasks for oneself and to solve them independently or under the guidance of a mentoring teacher.

Such independent activity which does not follow the school curriculum (when every step of the student is scheduled, and the student takes a passive position in the educational process) is similar to the activity of a scientist who is intensively and enthusiastically working on an invention. However, scientific activity is best carried out in a team of like-minded people. Therefore, the purpose of the technopark is to organize such team and provide a creative workshop. For this, it is necessary to analyze youth subcultures and to identify the features of new generations born in the era of computerization.

Youth subcultures are substantially covered in literature. A youth subculture in the educational environment of the university accumulates a certain system of values and attitudes (axiosphere), as well as a lifestyle (Kolesnik et al., 2020) which define it as a self-organizing valuemoral territory where a person can choose the ethical boundaries of life (Lukyanov et al., 2016) and also has the opportunity to test models of this life. According to Russian researchers (Lukyanov et al., 2016), the main models here are those of pleasure, utility, perfection and altruism. Notably, all the named models when applied to the idea of a technopark represent a single model defined as a way of implementing the social type of a scientist. In its fundamental attitude towards scientific creativity, this type combines altruism, pleasure, utility and the pursuit of excellence (skill). The authors of the present research believe such model will be a scientific and educational model of leisure activities, or 'a scientific and educational value', as this phenomenon is interpreted from an axiological point of view (Melnichuk et al., 2019).

In Russia, the idea of a technopark (i.e. a technology park) as a model of subcultural leisure activity is practically not considered, which substantiates the novelty of the present research. In Russia, a model of leisure activity is mainly referred to as sports cultural activities (competitions, sports days, sports and health tourism, and outdoor games) (Klinov \& Blotskiy, 2016).

The Strauss-Howe theory of generations (Strauss, 1997; Nosova, 2013; Albert et al., 2019) generated scepticism, yet gave impetus to the identification of the relationship between the worldview of individual groups of people and the framework of their life: a framework within the global historical and economic period and within the state (factors of the correlation of time, place and life position). The models of generation development and archetypes within these models (identified by foreign researchers) prompted Russian researchers to create a similar theory. The selection of the last generation (Generation Z, born since 2003 or, according to other data, since 2000 ) is based on the fast development of the Internet during this period, the active use of individual technical means of communication and access to information by 'digital people' (Sapa, 2014) rapidly maturing due to the unlimited flow of information. The main characteristics of this generation are the desire to realize oneself in society, a rich inner world, civic duty and morality, the desire to achieve professional excellence, microentrepreneurship, preference for studying electronic information systems, presentations, and multimedia (Shindryaeva, 2015).

Yet due to the fact that allocating archetypes of previous generations of Russians on the proposed scale is controversial, the authors of the present research choose a more democratic principle of ranking: the world of children (Generation Z), the world of parents (Generation $Y$ ) and the world of grandparents (Generation X). Such conditional classification is convenient for the 'children' respondents as it allows visualizing specific family members and easily differentiating them according to their value preferences. The authors believe that the comparison of data reflecting the views and values of generations will shed light on how 'digital persons' are able to preserve national values transmitted to them by previous generations, what values of the global world are perceived, and whether they are replacing national values. 
The issue of globalization changing the national values has been discussed for decades. Philosophers, psychologists, political scientists, sociologists, religious leaders - everyone who studies the intellectual potential of people is trying to build long-term forecasts predicting destruction of national value systems under the influence of global ones (Stolovich, 2004; Adolfi, 2010; Motroshilova, 2010) or describing their mutual influence (Poplavskaya, 2020). Due to the fact that the world of values is a guide to action for a specific person, negative results of these actions are possible, such as a morality crisis that can destroy civilization. Recently, linguists, in alliance with teachers and sociologists, have also begun to actively consider the issue turning to its axiological component. This is due to the possibilities of researching the value content of the language of mass media and advertising connected with identifying the frequency and brightness of images and ideas of a different, free lifestyle for the sake of satisfying one's most sophisticated desires and of getting pleasure. As known, brightness and frequency of information is one of the most effective methods of motivation widely used in pedagogy, rhetoric, and other types of human interaction. A wellrhymed advertising slogan pronounced by the idol of the public from a wide screen can easily enter the system of values of society, especially of its exalted, youthful part. In this case, the slogan can be realized and declared as a value and enter the personal worldview of a representative of a societal group. If the research participants name this linguistic unit as also taking place in the minds of their parents and grandparents, i.e. of several previous generations, we can speak about either the stability of value and of its establishment in the value system, or about its conflict with other values presented in the worldview of a social group or the entire people, i.e. about its displacement. The problem of identifying the basic values of the Russian people at the level of concepts has already been considered (Shaposhnikova et al., 2018).

The present research raises the issue of the necessity to keep track of basic values in the national worldview, to identify groups of values among several generations of Russians - both the values functioning unchanged and the values undergoing changes, to indentify new groups of values and the possibility of intergenerational cultural dialogue.

Consideration of this issue requires large financial investments, analysis of the statements of a large number of respondents, involvement of professional sociologists and analysts, of linguists specializing in cognitive linguistics, and of teachers engaged in the philosophy of education and the axiology of education. This pilot study presents approaches to the problem, preliminary conclusions and methods of using text materials for analysis.

Due to the fact that the values of Russian youth, including Generation Z, are currently being widely and comprehensively studied (Kiryakova et al., 2020; Nemova et al. 2020; Bykov \& Nastina, 2020; Sychev et al., 2019; Kononenko et al., 2020; Podolskiy \& Idobaeva, 2019), the authors of the present research limited the field and chose a linguoaxiological approach that allows approaching the problem from the point of view of the respondents' texts, of worldview values fixed in language. The language reflects the spiritual and moral experience of the people and manifests universal values passed on from generation to generation and reflected in the ideas about good and evil, about the highest goals of a person, about work, family, etc. In other words, the language shows the intergenerational continuity of axiospheres.

The authors of the present research also aimed to trace how the identity of Russians (the feeling of ' $u s$ ') is reflected in the language and how the moral and ethical attitudes of the last three generations of Russians reveal the national worldview, its formation and possible changes. The moral regulators of the changing generations are fixed in the worldview; they are reflected in folk wisdom manifested in language as a cultural phenomenon. 


\section{METHODOLOGY}

The research materials were sociological surveys of young students conducted at Kuban State Technological University (Krasnodar, Russia) with the support of the Interregional Academy of Experimental Education and Innovative Technologies (Moscow, Russia). The survey participants were 128 1st-year students of technology and economics as well as entrants of Kuban State Technological University (that is, Generation Z, or the world of children). Some questions were as follows: 'Your outlook on life (write down your own thought, give any quote or slogan)', 'Formulate the basic judgments that guide your parents in life', and 'Formulate the basic judgments that guide your grandparents in life'. If the respondents wanted to answer with quotations but found it difficult to reproduce the quotations from memory, they were allowed to use the 'pocket Internet' or convey the content in their own words. If respondents were not ready to answer a question and put it in the answer form, they marked the item as 'Difficult to answer'. As a result, 205 responses were provided for the three above-mentioned open positions, and these answers served as the material for the research.

The methodological base of the research is represented by general and specific scientific levels. The philosophical basis of the research is the postulate on the relationship between language and society and on the reflection of the society worldview in its language; this allows analyzing the values of the Russian-speaking world through their expression in the linguistic means.

Within the framework of the general scientific level, the following research methods were used:

- functional - mental representation of a culturally determined value expressed by language units in speech while the respondent on the basis of social experience is forming an image of a phenomenon;

- experimental (in the form of an associative experiment) - a key method for studying a modern person's worldview;

- categorical analysis as a way of distributing the obtained data by headings, which allows identifying the signs and specifics of concepts, categories and values;

- conceptual analysis to classify cultural values identified by respondents during the associative experiment;

- descriptive;

- inductive.

\section{RESULTS}

The structure of the worldview includes knowledge, values, will, beliefs, principles, norms, ideals, feelings and emotions, and programs of action, and is reflected in the language. The authors of the present research were interested in mental representation reflected in the language, in judgments made about the world, in identifying the axiological (value) side of the worldview. Mental processes of perception and of understanding reality, as well as "types and forms of representations" of this reality (Popova \& Sternin, 2007, p. 12) are called 'cognitization' - the ordering of certain categories in the human mind, which allows storing and replenishing information. This process takes place within the concept sphere - "an organized set of units of the people's thinking" (Popova \& Sternin, 2007, p. 104) and reveals "mental signs of a phenomenon which are reflected in the consciousness of the people at this stage of its development" (Popova \& Sternin, 2007, p. 104). The concept as a "discrete mental formation which is the basic unit of a person's mental code ... and carries information about ... the attitude of public consciousness to a given phenomenon or object" (Sternin, 2005, p. 257) is based on stable ethnocultural ideas; therefore, the world of values can be represented through concepts. The notion 'a concept' includes not only the linguistic unit but also the image itself that underlies it (Maslova, 2011), includes a 
cognitive, non-linguistic, mental category, the idea itself (Evans, 2009), and is an interaction of factors such as national tradition, life experience, images of art and a system of values (Arutyunova, 1993). These provisions of cognitive linguistics (Evans, 2009; Talmy, 2000; Langacker, 2009; Glynn, 2009, p. 82; Glynn, 2010; Fischer, 2010; Vinogradova, 2014; Savoiskaya, 2014; Shapochkin, 2013; Rozina, 1994) allowed the authors of the present research to approach the identification of groups of values which act as concepts in the native speakers' worldview.

For research, group identity at the level of three generations of families was chosen; here, the attitudes of group members are well known to each member and can be freely reproduced in their natural language expression, i.e. there is a free intergenerational dialogue. Identity is also evidenced by the fact that a common feature of the respondents' families was the focus on higher education for the younger generation. Therefore, it can be assumed that the social group involved in research is focused on the development of civilization and the preservation of humanistic traditions, is the bearer of socially significant values, and is interested in their transmission in time (in the cultural continuity of generations) not only at the level of social attitudes but also at the level of activity (study, work, technical and cultural development of society). This social group is also characterized by orientation toward broader areas than family and professional ones, that is, toward multicultural, global scales in social development.

The respondents were asked to distribute family values into their own (the values of the world of children), their fathers' and mothers' values (the values of the world of parents), the values of generations more distant from them, such as their grandfathers' and grandmothers' values (the values of the world of grandparents); hence the conventional names used in the research.

Considering the answers of each respondent separately reveals that different, non-repeating replications are used to characterize each of the three worlds, which indicates the analytical approach of the respondents to the task.

Based on the types of worldview (everyday, philosophical, scientific, humanistic, mythological, etc.), nine main positions of value ranking were identified within each world:

(a) orientation towards overcoming any life difficulties;

(b) adherence to moral principles;

(c) adherence to philosophical principles;

(d) orientation towards work, study and education;

(e) value of family and health (which can be attributed to the existential layer of values);

(f) phraseological units and proverbs as expressions of social and global identity;

(g) mythological component of the worldview;

(h) values-orientations perceived from advertising and media;

(i) humorous assessment of life problems.

The latter two are quantitatively insignificant strata of values yet important for analyzing how values are formed and replaced.

The last position in the allocation of values is associated with the active entry of Russia into the Internet space and the development of new complex technical areas of activity by the young generation. Complex things are more easily perceived in combination with a joke; in the middle of the 20th century, Mikhail Bakhtin dubbed this 'laughter space of language' (Bakhtin, 1975), and this was actively manifested in Generation Z. 
Table 1. Quantitative content of value groups for three conditionally allocated generations

\begin{tabular}{lcccc}
\hline Ranking of values in the worldview (group of values) & $\begin{array}{c}\text { World of } \\
\text { grandparents }\end{array}$ & $\begin{array}{c}\text { World of } \\
\text { parents }\end{array}$ & $\begin{array}{c}\text { World of } \\
\text { children }\end{array}$ & $\begin{array}{c}\text { Total } \\
\text { 1. Overcoming any life difficulties }\end{array}$ \\
\hline 2. Moral principles & 8 & 5 & 5 & 13 \\
\hline 3. Philosophical principles & 4 & 16 & 13 & 37 \\
\hline 4. Study, education, work & 12 & 17 & 6 & 15 \\
\hline 5. Existential plane (family, health) & 18 & 17 & 15 & 34 \\
\hline 6. Phraseological units and proverbs as expressions of social & & & 50 \\
and global identity & 13 & 7 & 17 & 37 \\
\hline 7. Mythological component of the worldview & 1 & 1 & 2 & 4 \\
\hline 8. Values-orientations perceived from advertising and media & - & 3 & 6 & 9 \\
\hline 9. Humorous assessment of life problems & - & - & 6 & 6 \\
\hline Total & 59 & 71 & 75 & 205 \\
\hline
\end{tabular}

\section{DISCUSSION}

Due to the fact that the world of children directly participated in the survey, the children's judgments about themselves in quantitative terms slightly exceed information about the world of parents and significantly exceed information about the world of grandparents (75- $71-59$, respectively). The latter is explained by the lack of close and constant communication with grandparents in some cases.

Analyzing the types of value attitudes, it is noteworthy that the existential plane concerning family and health turned out to be the largest in terms of the number of assessments and the most identical in terms of distribution between groups: 18-17-15 (grandparents, parents and children, respectively). Such small discrepancy in the number of statements depends on the fact that family (the archetypal model of the structure of the world) was the first to be formed in the mind of a person as a value; therefore it accumulated a greater number of value characteristics. Yet the comparison of the content of these worlds will differ for the three generations - for instance, in the world of grandparents the main thing is family, happiness of children and grandchildren, good relationships, proper nutrition, warm clothes, etc., in the world of parents the main thing is family, health, career, good upbringing, material security of children and relatives, and in the world of children, the main thing is welfare for oneself and for loved ones, success and independence, adaptability, no personal problems or harming others, and a healthy lifestyle. Evidently, in each age group there is an indication of caring for others, which is the factor of identity. At the same time, the level of care decreases from the world of grandparents to the world of children.

The following two groups of values are few but approximately the same in the number of statements: the philosophical principles of the existence of three worlds $(4-5-6)$ and being oriented towards overcoming any life difficulties $(3-5-5)$.

The philosophical principles of children are broader, global (which is associated with a better acquaintance with world art) and more abstract: the essence of life is to find oneself; pride and honor are above all; life never changes, only your view of it changes, etc. In their content, they completely coincide with the philosophical principles of the world of grandparents (the essence of life is to find oneself; to remain human in any situation; to work to be useful to others) and the world of parents (to be human, to have the right attitude to life, to do what will entail benefit). This allows speaking about the absence of clarifications and substitutions of the worldview at the level of philosophical principles of being, and about a single positive worldview of three generations. In contrast to the world of children, the named values are more concrete and vital.

Positiveness is clearly expressed in the orientation of the three worlds towards overcoming any difficulties in life - the world of grandparents (never stop believing in yourself; live so that 
grandchildren take after you and are proud of you; help those who depend on you, do not abandon them in difficult times), the world of parents (through hardships to the stars; follow your dreams; no-one will fix the situation but oneself; we must achieve goals and move forward), and the world of children (nothing is impossible; never give up; who if not us). The highest emotionality of statements is characteristic of the world of children and wisdom of the world is characteristic of the world of grandparents. Overcoming life's difficulties is viewed by the worlds in an identical and positive way. This position in life is characteristic of the Russian worldview, testifies to group identity, the realization of the feeling of 'us' in the basic concepts of the worldview.

Parents are more aware of moral principles, according to children, judging from the quantitative ratio: $8-16-13$. In the world of grandparents, the focus is on helping people, on love for the homeland and life for the good of the country, as well as on discipline, responsibility, and respect for the word 'necessity'. The world of parents is dominated by honesty, decency, kindness, responsiveness, trust, concern for others, optimism, human attitude and the ability to do good. The world of children is dominated by honesty, humanity, pride, honor, the ability to benefit people, to stand up for oneself ('Do not let them wipe the floor with you'), the desire to achieve set goals by oneself ('Do not step on people to get ahead', 'Do not lose yourself chasing money'), positive reinforcement of one's actions ('Live in such way that they pay tribute to you with a monument and with kind words whenever they speak of you'). The world of children retains the main universal (terminal) values but thinks globally, does not put service to the homeland first, and at the level of terminal values sharply distinguishes a positive path and a negative path. For the world of grandparents and parents, such distinction is not important. Thus, in the world of children, the process of forming values is noted, since there is an unfolding of statements, a comparison of positive and negative, a desire to prove one's life attitude through opposing goals and values. Although the grandparents' focus on living for the good of the country is replaced by the parents' orientation towards trust, kindness and responsiveness and then by the children's orientation towards pride and honor, there is no conflict of values as they demonstrate a single humanistic worldview.

In quantitative terms, there is a sharp difference in attitudes towards studies, education, and work $(12-17-5)$. Although the content of the concept of study and work does not differ for three generations (the main thing is study, education; knowledge gives you a lot, you are to learn and develop), the world of grandparents focuses on work as a consequence of successful studies, the world of parents focuses on studying for the sake of providing for the future family, and the world of children on the opportunity to learn as much as possible and get a profession. That is, each generation sees different goals of education based on their life experience. The quantitative difference in the values of the worlds is associated with the frequency of attention paid to the need for study and work in conversations between older generations and younger generations.

The most ancient foundations of the language reflecting the nationwide dominants of values are of greatest importance for determining the identity of generations in the worldview. These are phraseological units, sayings, proverbs, rhymed passages or modern texts with a high degree of coherence (more often catchphrases or folk ideas). In quantitative terms, they correlate as $13-7-$ 17. These expressions encompass both the existential plane and moral and philosophical principles and serve as the moral regulators of the life of society, therefore occupying an important place in the worldview. The existential plane is represented by the set expressions associated with the labor process (common for the three worlds and most frequently used in Russian): measure twice, cut once; no work, no meal; business before pleasure; slow and steady wins the race; diligence is the mother of success; he who would catch fish must not mind getting wet.

Phraseology is the foundation of folk wisdom, enshrined in the worldview; it is invariably presented in the minds of generations. The rest of the sayings and catchphrases indicated by the respondents dominate with different frequencies in the worldview of three generations but are 
united by a common positive orientation: one must not only believe in good - good must also be done; while I breathe, I hope; in dialogue with life, it is not its question that is important but our answer; if you fell down yesterday, get up today; there are no keys to happiness - the door is always open; if stars are lit, it means there is someone who needs it.

In the above-mentioned value attitudes, not only catchwords of Russian authors dominate, which indicates the process of changing the narrow national worldview, indicates the desire for global, universal thinking in the development of values. If we analyze the children's worldview, the vast amount of quotes from the world culture attracts attention: Sing like no one is listening, love like you never been hurt, dance like no one is watching and live like it is heaven on earth (Mark Twain); Train with those who are stronger, love those who are out of your league, do not give up where others surrender, and you will win where you cannot win! (Bruce Lee); If at least one flowering branch is left in your soul, a singing bird will always sit on it. Life is full of beauty. Pay attention to this. Breathe in the smell of rain and feel the wind. Live and fight for your dreams (interpretation of an Eastern saying) (the authors of the quotes were identified and indicated during the preparation of the material for publication). As can be judged by the content of the quotes, the general Russian worldview is actively supplemented by the world of children; moreover, within the position of overcoming any life difficulties, optimistic children found the global value closest to their age, which allows them to expand the worldview without changing its stable parameters.

Such attitude as optimism, presented only in the world of children, is highlighted as an independent value - the humorous approach to life problems: Accidents do not happen by accident. Do not hang out with idiots who do not help you shine. A dead end is a great reason to break walls. What does not kill us will regret it. Linguistic analysis shows that such textual reminiscences (complete or incomplete quotes that arise independently of the speaker's will) allow the speaker to join a well-known opinion in society, quite new in the linguistic consciousness of the people. This opinion seems correct to the speaker, i.e. approaches the role of phraseological units which reflect the deepest layers of the society world view. Evidently, the above mentioned textual reminiscences are a collection of slang forms, borrowings and scathing ridicules by the Strugatsky brothers, black humor - everything that the Internet lives on, and this pushes towards a vivid manifestation of one's own ' $I$ ' and the formation of an independent position, and reflects nihilism of youth.

In the world of parents and in the world of children, in contrast to the world of grandparents, orientation towards advertising, media and websites is one of the values at the ratio of $3-6$ : Life for yourself. Live for your pleasure. We live once - you have to try everything. Life should be lived in such way that you get married in a Valentino dress and die in a CHANEL suit. As the quantitative ratio shows, in the world of children consumer values are twice as high as in the world of parents. Therefore, we can speak about the rapid formation of these new values; moreover, they oppose the values of the world of grandparents, directed not at themselves but on the good of the homeland. Serving the homeland and working in the name of it are no longer represented in the world of parents, replaced by consumer values.

However, analyzing the above statements, the position of the interpreter must be taken into account: the assessment of good and evil occurs from the position of the society or an individual. The peaceful life of Russia, bought through suffering with great blood and terrible casualties will not be weighed on the same scales with the personal happiness of individuals. At the same time, all the generations fought stoically for the happiness of their descendants. Calls for this happiness now come into conflict with the attitudes towards rallying and repelling common enemies, reflected in the worldview. Here, we are dealing with the so-called 'access point' (Evans, 2009), i.e. the position of the observer with which they consider the phenomenon and evaluate its usefulness or harmfulness. What was a tough moral law, the possibility of survival for one historical time and one generation, will no longer be a tough norm for another generation living in another era, although the moral code laid down in the value system will work if you have to assess the situation from 
another historical time presented in a book or on screen. For example, the statement Life should be lived in such way that you get married in a Valentino dress and die in a CHANEL suit can be uttered with rapture or with mockery or condemnation depending on the cognitive model realized by the speaker. Outside the oral speech context, it is impossible to identify which value content the written phrase has for the author - one can only assume implicit (hidden) assessment (Hunston, 2011).

The mythological component of the worldview is the smallest in the quantitative aspect (11 - 2). This category differs in content across generations and shows a tendency to move from humility to an active reorganization of life - the world of grandparents (nothing happens just like that, God won't give you more than you can handle), the world of parents (as destined, it will be), and the world of children (do what you must, and come what may, do not wait for surprises and gifts from life, you have to make life yourself). Thus, the world of children is moving away from conservatism towards the manifestation of love of life, which is again characteristic of youth.

The picture of values presented here in the worldview of Russians cannot be considered complete as the issue remains insufficiently studied. It requires significantly more research material received from respondents, involvement of other categories of the population in the surveys, and not just students of leading universities of technology. Yet the provisions highlighted in this pilot study can serve as a starting point in further research, and can confirm, expand, develop or refute the judgments and ideas presented here.

\section{CONCLUSION}

1. Psychological and pedagogical research aimed to clarify the features of the axiosphere of Generation $\mathrm{Z}$ in connection with solving the problem of attracting it to the creative groups of the technopark.

2. It was found that the identity of the three conditionally distinguished generations of Russians is manifested in a general orientation towards terminal values, in the assertion of a humane position in relation to people, is characterized by a focus on work and study, caring for others, and achieving life goals with own labor. These qualities are represented by the first five ranks of values (moral and philosophical principles of existence, views on study, work, family and health, overcoming life difficulties, deep folk wisdom, reflected in phraseology and sayings). These terminal values dominate quantitatively (196 statements out of 205), which is $96 \%$ of the total number of representations.

3. Focus on the values offered by the media and advertising makes up only 9 units of representation, which corresponds to $4 \%$ of the total number of representations. From this we can conclude that the Russian mentality is resistant to the introduction of the philosophy of buying and selling. It should be noted that the world of grandparents is saved from the dominance of advertising by a different age orientation and deep national values, and the world of children is protected from this by the already developed 'antidote' - irony ( 6 representations, or $3 \%$ ). Most of all, the problem of the media worries the world of the parents - they have not yet developed the 'antidote'.

4. Global identity is manifested in a large-scale expansion of the horizons of Generation Z, which is facilitated by the Internet with its widest access to information and opportunities for selflearning.

5. There is a weakening of the focus on the defense of the homeland even among the world of grandparents is weakening (only three representations), and it is completely absent in the world of parents and in the world of children, but at the same time all three worlds are identical in their humane philosophical and moral attitudes. This feature, apparently, is dictated by the general world development and globalization, is reflected in the consciousness of the people at this stage of its development and manifested in the worldview of native speakers. 
6. The different content of the concepts of work and study was recorded in different generations. Thus, the world of grandparents focuses on work as a consequence of successful studies, the world of parents on the process of studying for the sake of providing for the future family, and the world of children on the opportunity to learn as much as possible and get a profession.

7. Globalization affects the world of values for all the three generations involved in the analysis. In the world of grandparents, a gradual tendency towards the loss of values (weakening of the position of defending the homeland) is noted, in the world of parents the replacement of values (the entry of media values and the loss of the value of defending the homeland) is noted, and the world of children demonstrates a boost in values (humorous perception of the world).

8. The analyzed representations reveal the life-affirming nature of the Russian worldview, reflected in the world outlook of those in the vanguard of Generation Z, and the possibility of intergenerational cultural dialogue.

In the future, the authors are planning studies that will answer the question of whether the set of values changes by the end of study at the university, whether there is a connection with growing up, whether the identified set of values was set as a result of preparing for Russia's Unified State Examination, since literary texts that are offered to school graduates for analysis are valueoriented and require a humanistically directed statement, the determination of one's own opinion, and a positive solution to the problem. The educational function of humanitarian academic subjects and humanistic Russian literature is invaluable, but life imposes its own adjustments on a person's worldview. Although this research demonstrated the unity of the worldview of three generations, the authors consider it premature to make unambiguous conclusions; therefore, they emphasize once again this study was conducted on the basis of the ideas of those in the vanguard of Generation Z.

\section{Authors' Contributions:}

Alexander M. Gerashchenko: conception and design, acquisition of data, analysis and interpretation of data, drafting the article, critical review of important intellectual content. Tatyana L. Shaposhnikova: conception and design, acquisition of data, analysis and interpretation of data, drafting the article, critical review of important intellectual content. Oksana R. Tuchina: conception and design, acquisition of data, analysis and interpretation of data, drafting the article, critical review of important intellectual content. Olga A. Gordienko: conception and design, acquisition of data, analysis and interpretation of data, drafting the article, critical review of important intellectual content. Alena $Y$. Egorova: conception and design, acquisition of data, analysis and interpretation of data, drafting the article, critical review of important intellectual content. All authors have read and approved the final version of the manuscript.

Ethics Approval: Not applicable.

Acknowledgments: The research was carried out with the financial support of the Kuban Science Foundation in the framework of the scientific project No. IFR 20.1/36. The authors express their gratitude to the founders of the competition for the best scientific projects of interdisciplinary fundamental research on the topic 'Human capital: competitiveness, intelligence, giftedness', who proposed to study the features of the formation of human capital in Russia and a database on its state and territorial characteristics. The authors also express their gratitude to the Kuban Science Foundation which in 2020 launched an initiative for research in the field of pedagogy and psychology and for the development of modern educational technologies and new approaches to teaching gifted children and youth. All this allowed conducting the present research as a pilot on the territory of the Southern Federal District of Russia and outline the prospects for subsequent large-scale sociological, psychological and pedagogical research which will answer the most pressing question of our time: what should be expected from Generation Z, which path Russia's development and that of globalizing world will take, and on the importance of technoparks (including school ones) for the value orientation of Generation Z. 


\section{REFERENCES}

Adolfi, R. (2010). The epoch of globalization and the problem of humanistic values. The Journal of Philosophy and Social Sciences, 1, 51-55.

Albert, M., Hurrelmann, K., Leven, I., Quenzel, G., \& Schneekloth, U. (2019). The utility of the term "generation' in sociology and youth research. A reply to Martin Schröder's thesis on the "Generation Myth". Kölner Zeitschrift für Soziologie und Sozialpsychologie, 71 (3), 457-469.

Arutyunova, N.D. (1993). Introduction. In Arutyunova, N. D. \& Ryabtseva, N.K. (Eds.) Logical analysis of language. Mental acts (pp. 3-6). Nauka.

Bakhtin, M.M. (1975). Rabelais and Gogol (the art of word and the folk culture of laughter). In Bakhtin, M.M. Questions of literature and aesthetics. Studies of different years (pp. 496-485). Khudozhestvennaya literatura.

Bykov, A.V. \& Nastina, E.A. (2020). Link of the value attitudes with career achievements (based in a survey of youth). Sociological Studies, 8, 67-77.

Brito, R. dos S., Prado, J. R., \& Nunes, C. P. (2017). As condições de trabalho docente e o pós-estado de bem-estar social. Revista Tempos e Espaços em Educação,10(23), 165-174.

Evans, V. (2009). Semantic representation in LCCM theory. In Evans, V. \& Pourcel, S. (Eds.), New directions in cognitive linguistics (pp. 27-56). John Benjamin's Publishing Company.

Fischer, K. (2010). Quantitative methods in Cognitive Semantics. Introduction to the volume. In Glynn, D. \& Fischer, K. (Eds.), Quantitative methods in Cognitive Semantics: Corpus-driven approaches (pp. 43-59). Walter de Gruyter.

Glynn, D. (2009). Polysemy, syntax, and variation. A usage-based method for Cognitive Semantics. In Evans, V. \& Pourcel, S. (Eds.), New directions in cognitive linguistics (pp. 77-104). John Benjamin's Publishing Company.

Glynn, D. (2010). Corpus-driven Cognitive Semantics. Introduction to the field. In Glynn, D. \& Fischer, K. (Eds.), Quantitative methods in Cognitive Semantics: Corpus-driven approaches (pp. 1-42). Walter de Gruyter.

Hunston, S. (2011). Corpus approaches to evaluation. Phraseology and evaluative language. Routledge.

Kiryakova, A.V., Chelpachenko, T.V., Shabalina, L.G., Maslova, A.I., Zhukov, V.A., Makarov, A.L., Aleksandrova, E.A., \& Popova, O.V. (2020). Value orientations: What portrait of modern students is? Revista San Gregorio, 37, 1-9.

Klinov, V. \& Blotskiy, S. (2016). Forming senior school students' values of leisure at rural schools in the course of physical education. Science and Education, 8, 79-85.

Kolesnik, E.A., Stepanov, V.G., \& Pavlova, LL. (2020). The Study of the phenomenon of the youth subculture and its place in the cultural and educational environment of the Russian higher education institution. Amazonia Investiga, 9 (26), 88-96.

Kononenko, O., Kononenko, A., Stynska, V., Kachmar, O., Prokopiv, L., Katolyk, H., \& Popovych, I. (2020). Research of the factor structure of the model of world view settings at a young age. Revista Inclusiones, 7 (3), 98-116.

Langacker, R. (2009). Constructions and constructional meaning. In Evans, V. \& Pourcel, S. (Eds.), New directions in cognitive linguistics (pp. 225-268). John Benjamin's Publishing Company.

Lukyanov, O.V., Chastokolenko, J.B., \& Kotikova, K.O. (2016). Freedom authentication in creative youth subcultures. Siberian Journal of Psychology, 61, 91-108.

Maslova, V.A. (2011). Concepts and values: the contents of meanings and their language interpretation. Scientific Notes of Taurida National V.I. Vernadsky University. Series "Philology. Social Communications", 24 (63), $383-387$.

Melnichuk, M.V., Gruzina, Y.M., \& Firsova, I.A. (2019). Formation of scientific and educational values in the system of youth motivation. Economic and Social Changes: Facts, Trends, Forecast, 12 (6), 260-275.

Motroshilova, N.V. (2010). Civilization and barbarism in an epoch of global crises (2nd ed.). Institute of Philosophy, Russian Academy of Sciences.

Nemova, O.A., Vagin, D.Y., Tsyplakova, S.A., Bystrova, N.V., Kutepova, L.I., \& Kozlova, I.M. (2020). Labor values and labor attitudes among students of secondary vocational schools in Nizhny Novgorod: as revealed by the sociological survey. International Journal of Applied Exercise Physiology, 9 (2), 73-80.

Nosova S.S., \& Kuzheleva-Sagan, I.P. (2013). Youth in network information and communicative society: Foreign approaches to study issues. Siberian Journal of Psychology, 49, 85-96. 
Podolskiy, A.I. \& Idobaeva, O.A. (2019). Quo vadis? Trajectories of value-motivational development of modern Russian youth. Voprosy Voprosy Psychologii, 2, 45-58.

Poplavskaya, A. (2020). What do we know about 21st century youth? American teens through the eyes of a psychologist. Journal of Economic Sociology, 21 (3), 84-100.

Popova, Z.D. \& Sternin, I.A. (2007). Cognitive linguistics. AST: Vostok-Zapad.

Rozina, R.I. (1994). Cognitive and taxonomic relations. Categorisation of the world in language and in text. Topics in the Study of Language, 6, 60-78.

Sapa, A.V. (2014). Generation Z - the generation of the FSES epoch. Innovative Projects and Programs in Education, 2 , 24-30.

Savoiskaya, N.P. (2014). New directions in modern cognitive linguistics. Issues of Cognitive Linguistics, 2 (39), 83-89.

Shaposhnikova, T.L., Tuchina, O.R., Gordienko, O.A., Rus-Bryushinina, I.V., Zinkovskaya, V.E., Apollonov, I.A., Mukha, V.N., Romanov, D.A., Lyalyuk, A.V., Egorova, A.Yu., Rykhalsky, Yu.S., Teryukha, R.V., Glukhenkiy, I.Yu., Kotlyarova, E.A., Tarasenko, N.A., Romanova, M.L., \& Rykova, E.V. (2018). Digital humanities in the conditions of the educational environment of the south of Russia at the service of tolerance (axiological component in teaching Russian to foreign students). Kuban State Technological University.

Shapochkin, D.V. (2013). Cognitive discourse analysis in linguistics. Bulletin of Chelyabinsk State University, 10 (301), 101-107.

Shindryaeva, I.V. (2015). Professional value orientations of youth in the context of generational theory. Bulletin of the Volga Region Institute of Administration, 6 (51), 145-148.

Silva, L. R., Santos, A. R., \& Santos, I. T. R. (2020). Public policies for education of/in the field and the school environment in a settlement of the MST: the intimate relationship with the pedagogical policy. Journal of Research and Knowledge Spreading, 1(1), e11737.

Sternin, I.A. (2005). Types of meanings and concept. In Kubryakova, E.S. (Ed.), Conceptual space of language (pp. 257282). Tambov State University Publishing House.

Stolovich, L.N. (2004). On values common to all mankind. Problems of Philosophy, 7, 86-97.

Strauss, W. \& Howe, N. (1997). The fourth turning: An American prophecy - What the cycles of history tell us about America's next rendezvous with destiny. Crown.

Sychev, O.A., Belousov, K.I., \& Protasova, I.N. (2019). Values and moral foundations as a basis for the socio-political views of youth. Siberian Journal of Psychology, 73, 60-77.

Talmy, L. (2000). Toward a cognitive semantics. MIT Press.

Vinogradova, S.A. (2014). Cognitive linguistics on meaning and concept. Issues of Cognitive Linguistics, 2, 50-55.

Received: 11 March 2021 | Accepted: 19 April 2021 | Published: 2 May 2021

This is an Open Access article distributed under the terms of the Creative Commons Attribution License, which permits unrestricted use, distribution, and reproduction in any medium, provided the original work is properly cited. 